\title{
Attitudes of Livestock Keepers to Breeding Strategies - Threats and Opportunities for on-farm Conservation of the Borana Cattle Breed
}

\author{
Kerstin K. Zander (Corresponding author) \\ School for Environmental Research, Charles Darwin University \\ Ellengowan Drive, Darwin NT 0909, Australia \\ Tel: 61-8-8946-7368Ｅ-mail: kerstin.zander@cdu.edu.au
}

Received: September 14, 2010 Accepted: October 9, 2010 doi:10.5539/jas.v3n2p3

The research was financed by the Robert Bosch Foundation, Stuttgart, Germany (Sponsoring information)

\begin{abstract}
Environmental and market pressures strongly affect cattle breeding in East Africa. While optimising breeding with diverse genetic material can improve income from cattle production, it can also lead to a loss and depletion of valuable animal genetic resources. This study assesses livestock-keepers perceptions of breeding strategies for the Borana breed and provides empirical evidence for livestock-keepers' awareness of different factors related to the improvement and survival of the breed. Knowledge of breeding with exotic cattle breeds was found to be relatively poor, particularly in Ethiopia, with livestock-keepers in Kenya being more receptive to the practise. In Kenya, crossing with exotic breeds is the main threat to survival of the Borana breed while in Ethiopia the major threat is dilution of Borana genetic material with that of other locally available breeds. Overall the breeding preferences of Ethiopian livestock-keepers' seem most conducive to de-facto or on-farm conservation programmes for the Borana breed.
\end{abstract}

Keywords: Animal genetic resources, Borana breed, East Africa, Livestock conservation, Ordered probit model, Pastoralism

\section{Introduction}

Livestock systems in developing countries are characterised by rapid change. Population growth, urbanisation and increases in demand for livestock products are combining at an unprecedented rate with environmental factors such as climate change to reduce pasture productivity. According to the International Panel on Climate Change (IPCC, 2007, Chapter 9), "Africa is one of the most vulnerable continents to climate change and climate variability, a situation aggravated by the interaction of 'multiple stresses', occurring at various levels, and low adaptive capacity. Global environmental changes can have devastating effects on livestock-keepers pursuing pastoral nomadic or semi-nomadic lifestyles in arid and semi-arid regions (Blackburn, 2007; Herrero et al., 2010). Pastoralists are highly vulnerable because they have few sources of income. Many livestock-keepers in developing countries, already under pressure from factors such as privatisation of land and population growth, can lose their entire stock to natural catastrophes like droughts and floods. Because of extreme poverty and a lack of alternative sources for food, pastoralists often come to depend on outside aid for food or to restock herds. To avoid external help, strategies to cope with change are essential for poverty alleviation. Responding to changes in livestock production systems is much more difficult than in crop production systems because of the long production cycle of animals. It takes years to change a breeding strategy, for instance, while buying different seeds, changing crop rotation times or switching to other crops may all occur in a single season. Coping strategies are manifold, although opportunities to leave the agricultural production sector are usually scarce in developing countries. One strategy is to adjust breeding strategies for livestock. Changes to the breeding strategy can either be reactive, as in choice of breeds for fast restocking of herds after a natural disaster, or anticipatory, such as breeding to adapt to expected adverse conditions of markets and environments.

Borana livestock-keepers are pastoralists making a living from the production of Borana cattle (Coppock, 1994). However, their lifestyles are rapidly changing from peripatetic pastoralism to more sedentary lifestyles (Fratkin and Roth, 2005). As a result new opportunities such as the cultivation of crops and the purchase of non-Borana 
cattle breeds have arisen. These changes in lifestyle and in cattle breeding strategies have lead to dwindling numbers of Borana cattle and therefore a loss of valuable genetic material of this traditional breed (Zander and Drucker, 2008). Animal genetic resources (AnGRs) of farm animals contribute to global diversity and are essential for insuring future livelihoods (Drucker et al., 2001; FAO, 2007), particularly in developing countries. Research on the existing values of species and breeds and their genetic material has flourished within the last few years (e.g. Ouma et al., 2007; Omondi et al., 2008; Ruto et al., 2008; Zander and Drucker, 2008, Vidogbèna et al., 2010). However, there is very little literature on the perception of local livestock-keepers towards the threat to local breeds and their preferred breeding strategies. These two factors are important when assessing which livestock-keepers would be likely to conserve a breed and its genetic resources de-facto and when selecting households for participation in on-farm conservation programmes. The selection of species and breeds for animal production depends not only on livestock-keepers' attitudes and perceptions but also on available inputs and their knowledge of breeds/species. Often livestock-keepers are forced to take immediate action after sudden changes such as droughts or diseases have occurred. Other changes, such as in market structures, allow them to adapt their breeding strategies gradually to the new situation.

The aim of this study is to undertake an empirical assessment of Borana peoples' perceptions of change to their environment, in their breeding management and of threats to their breed of cattle. A further aim is to identify heterogeneity among different groups of livestock-keepers in their attitudes to draw implications for improved breeding management. Empirical results are received from analysing answers on a Likert scale, gathered in a survey in the Borana lowlands in northern Kenya and southern Ethiopia, two areas undergoing institutional changes and frequently affected by droughts and famine.

\section{The study area, survey procedure and model specifics}

\subsection{The research area - environmental and social changes}

The lowlands of Ethiopia below $1500 \mathrm{~m}$ cover $65 \%$ of the country. They are home for about $12 \%$ of the human, and $26 \%$ of the estimated livestock, population of Ethiopia. In Kenya, pastoralist societies occupy $70 \%$ of the total land area but number fewer than 2 million out of Kenya's total population of 30 million (Fratkin and Roth, 2005). The Borana clans are one of the Oromo-Borana migrant groups from the southern highlands of Ethiopia who are believed to have reached Kenya in the $15^{\text {th }}$ Century (Schlee, 1989). Over the last 500 years the Borana people have maintained a complex indigenous socio/political structure, their traditional gada system, that governs their pasture management (see Coppock, 1994 and Solomon et al., 2007 for more details on the Borana society).

Ethiopia and Kenya are frequently affected by cycles of drought and floods. While the climate in the Borana lowlands is semi-arid, with average annual rainfall ranging between $350 \mathrm{~mm}$ and $900 \mathrm{~mm}$ in Ethiopia (Kamara, 2000), droughts have occurred in the southern part of Ethiopia in 1984/85 (worst drought so far), 1991/92, 2000 (second worst after 1984), 2002, and 2006. The droughts in 1984, 1991/92, 2000 and 2006 also had a severe impact on the northern part of Kenya. Close to $70 \%$ of the regional herds in Ethiopia was lost during the 1991/92 drought alone (Coppock, 1994) and 80\% of livestock was again lost during the drought 2005/06 (ILRI, 2006). At the same time, the vegetation and land cover have gradually changed from pasture to woody vegetation (bushes and shrubs), not suitable for grazing cattle (Coppock, 1994) and existing pastures have become desiccated.

More recently land in this area is being privatized and converted to cropland, causing pastoralists to lose access to former pasture land (Homann et al., 2008). Population pressure has exacerbated the rate of change in land use. Such changes have significant negative impacts on pasture productivity and the decisions Borana pastoralists make about managing their herds. Markets are also driving pastoralists' herd management. With better access to urban markets (because of improved infrastructure) and the prospect of higher prices for meat, pastoralists have started to improve herd productivity through breeding. Improved infrastructure enables local pastoralists to participate in bigger markets in urban areas and even between countries.

\subsection{Sampling, data collection and survey procedure}

In total 364 interviews were conducted (Ethiopia 244 interviews among four peasant associations in Didi Hara, Finchawa, Wachile, Web; Kenya 120 interviews in four locations in Marsabit district, northern Kenya: Badasa, Burbisa, Kijiji and Rukesa). The villages were selected because of the experience of the villagers with Borana cattle husbandry and proximity to roads. Households were sampled randomly. Field research took place between October 2003 and January 2004, following a pilot phase in July/August 2003. A semi-structured questionnaire was used to collect data on household and animal characteristics. Respondents were then asked to answer nine questions on a Likert scale in order to reveal their attitudes to various issues (see next section). 


\subsection{The ordered probit model}

An ordered probit model was applied to the data derived from respondents' answers on the Likert scale. The underlying attitudes of livestock-keepers to the threats to Borana cattle, their environment and their breeding strategies were investigated to reveal their capacity to adjust their breeding management.

For each of the following five questions respondents had to circle one of the options on a Likert scale: " $0=$ unsure; 1 = do not agree; $2=$ partly agree; 3 = fully agree".

1) The composition of cattle herds in my district have changed over the past 10 years.

2) It has become harder to find the traditional large framed Borana breed on local markets.

3) The traditional large framed Borana breed is at risk of extinction.

4) Keeping exotic cattle is inevitable for higher production and income.

5) The amount of land where I can graze my cattle decreased over the last 10 years.

A further four questions had the following options: " $0=$ unsure; $1=$ not important at all; $2=$ important; $3=$ very important".

6) How important is keeping the traditional large framed Borana for you?

7) How important is the crossbreeding of the Borana with other local breeds for you?

8) How important is buying, keeping and rearing exotic breeds for you?

9) How important is the crossbreeding of the Borana with exotic breeds for you?

For the model, I assumed that livestock-keepers' attitudes were determined by their characteristics. This relationship can be written as:

$$
y_{\mathrm{i}}^{*}=\beta^{\prime} \mathrm{x}_{i}+\varepsilon_{i}
$$

Where $y_{i}^{*}$ is the dependent variable reflecting the attitudes as stated by respondents, referred to as the underlying latent variable that drives the choice between the options (0,1,2 or 3) (Verbeek, 2000). $y_{i}{ }^{*}$ is derived from the observed counterpart $y_{i}$. Respondents' answers are not precise but can only be observed to lie in certain ranges, the "threshold" parameters $\mu . X_{i}$ is a vector of observable livestock-keepers' characteristics and $\varepsilon_{i}$ is a vector of unobservable livestock-keepers characteristics (the error term which is $\mathrm{N}[0,1]$ distributed). Given the four options from which respondents can chose, the qualitative dependent variable $\left(y_{i}\right)$ can be modelled as follows:

$$
\mathrm{y}_{i}=\left\{\begin{array}{lll}
0 & \text { if } & \mathrm{y}_{i}{ }^{*} \leq \mu_{0} \\
1 & \text { if } & \mu_{0}<\mathrm{y}_{\mathrm{i}}{ }^{*} \leq \mu_{1} \\
2 & \text { if } & \mu_{1}<\mathrm{y}_{\mathrm{i}}{ }^{*} \leq \mu_{2} \\
3 & \text { if } & \mathrm{y}_{\mathrm{i}}{ }^{*}>\mu_{2}
\end{array}\right.
$$

The $\mu$ 's were estimated along with the $\beta$ 's of the model. The probabilities of observing $y_{\mathrm{i}}$ given $x_{\mathrm{i}}$ can be expressed as:

$$
\begin{gathered}
\operatorname{Pr}(\mathrm{y}=0)=\Phi\left(-\beta^{\prime} \mathrm{x}\right) \\
\operatorname{Pr}(\mathrm{y}=1)=\Phi\left(\mu_{1}-\beta^{\prime} \mathrm{x}\right)-\Phi\left(-\beta^{\prime} \mathrm{x}\right) \\
\operatorname{Pr}(\mathrm{y}=2)=\Phi\left(\mu_{2}-\beta^{\prime} \mathrm{x}\right)-\Phi\left(\mu_{1}-\beta^{\prime} \mathrm{x}\right) \\
\operatorname{Pr}(\mathrm{y}=3)=1-\Phi\left(\mu_{2}-\beta^{\prime} \mathrm{x}\right)
\end{gathered}
$$

Where $\Phi$ is the standard normal cumulative distribution. For all positive probabilities, it is given that $0<\mu_{1}<\mu_{2}$ (Greene, 2003). Estimation was based upon maximum likelihood with the above mentioned probabilities ( $\mathrm{Pr}$ ) entering the likelihood function (Verbeek, 2000). While the estimated coefficients themselves have to be treated with caution, inference of the marginal effects of the dependent variable on the independent ones is possible (Greene, 2003). The marginal effects are calculated for each of the four probabilities:

$$
\begin{gathered}
\partial \operatorname{Pr}(y=0) / \partial \mathrm{x}=\Phi\left(-\beta^{\prime} \mathrm{x}\right) \times \beta \\
\partial \operatorname{Pr}(y=1) / \partial \mathrm{x}=\Phi\left(-\beta^{\prime} \mathrm{x}\right)-\Phi\left(\mu_{1}-\beta^{\prime} \mathrm{x}\right) \times \beta \\
\partial \operatorname{Pr}(y=2) / \partial \mathrm{x}=\left[\Phi\left(\mu_{1}-\beta^{\prime} \mathrm{x}\right)-\Phi\left(\mu_{2}-\beta^{\prime} \mathrm{x}\right)\right] \times \beta
\end{gathered}
$$




\section{Results}

$$
\partial \operatorname{Pr}(y=3) / \partial \mathrm{x}=\Phi\left(\mu_{2}-\beta^{\prime} \mathrm{x}\right) \times \beta
$$

\subsection{Respondents' characteristics}

The analysis showed that $84 \%$ of the households in Ethiopia depended on both livestock and crop production (referred to as agro-pastoralism or mixed-farming) for their livelihoods while only $16 \%$ were solely pastoralists (Table 1). In Kenya, 59\% were pastoralists while only $41 \%$ were agro-pastoralists. All respondents kept cattle, $57 \%$ kept sheep, $73 \%$ goats and 32\% camels (Table 1). In Kenya the average herd size was 20 adult cattle, in Ethiopia it was 18 adult animals with the largest herd consisting of 200 animals. In Kenya, the average herd size did not differ significantly between pastoralists and agro-pastoralists while in Ethiopia pastoralists kept, on average, six animals more in their herds. The rate of female to male animals was nine to one in Ethiopia and nine to three in Kenya. When three males were kept in a herd, often only one of them was kept as a breeding bull while the others were castrated and used for traction. Maximizing females while keeping males at the minimum number needed for effective breeding and food security was also found by Coppock (1994). The average number of sheep and goats was eight animals per household; the number of camels 1.5 per household.

[Table 1 here]

About $54 \%$ of respondents in Ethiopia and $82 \%$ in Kenya were literate. The average number of household members was six in both countries. Households mean income from cattle production was $€ 77$ in Ethiopia and $€ 84$ in Kenya. The minority of interviewed households were lead by women and only a few respondents considered themselves village chiefs.

\subsection{Respondents' perceptions for different breeding strategies}

The most commonly used socio-economic variables (see Table 1) were included as independent variables of the model, as well as some variables describing cattle production systems. Dummy variables (coded 1/0) were used for: country $($ Kenya $=1$; Ethiopia $=0$ ), education $($ Literate $=1$; Illiterate $=0$ ), gender of head of household $($ Female $=1$; Male $=0)$, social status within village $($ Chief $=1$; Not chief $=0)$ and production system (Pastoralism $=1$; Agro-pastoralism $=0$ ). Income from cattle production $(\mathrm{Inc})$, age of respondent (Age), number of household members (N_HH) and number of cattle kept (N_cattle) were entered as numeric variables.

Table 2 shows the frequencies of answers chosen on the Likert scale. One probit model was applied for each question, i.e. nine in total, and all models were tested for best fit using log-likelihood ratio tests. The two variables "Inc" and "N_HH" did not influence respondents" answers on the Likert scale at all and were dropped from the final models. In contrast the variables "Kenya" and "Pastoralism" had significant impacts on many of the responses (Table 3).

\section{[Table 2 here] \\ [Table 3 here] \\ [Table 4 here]}

\subsubsection{Country-specific heterogeneity}

Many of the livestock-keepers' perceptions (7 out of the 9 questions) varied significantly between Kenya and Ethiopia, particularly with respect to attitudes towards the breeding and husbandry of exotic breeds. Three questions $(4,8$ and 9$)$ referred to breeding with exotic breeds. The share of livestock-keepers that considered crossbreeding of exotic and Borana animals as very important ( $y=3)$ was $36 \%$ higher in Kenya than in Ethiopia (see the marginal effects in Table 4). In Ethiopia, on the other hand, the share of respondents being unsure about this question ( $\mathrm{y}=0$ ) was $54 \%$ higher than in Kenya. An inability to answer whether the breeding for higher productivity and income is inevitable (Question 4) was 50\% higher in Ethiopia than Kenya. The share of people stating that the husbandry of pure exotic cattle is very beneficial $(y=3)$ was $40 \%$ higher in Kenya than in Ethiopia. The share of people answering "very important" with respect to the importance of exotic breeds in a herd was $44 \%$ higher in Kenya, and again, the proportion of people not answering this question is $53 \%$ higher in Ethiopia. In Kenya, $12 \%$ fewer respondents than in Ethiopia thought that rearing exotic breeds was not important at all $(\mathrm{y}=1)$.

While having concerns for breeding with exotic breeds, the share of livestock-keepers that considered crossbreeding of the Borana with other local breeds (Question 7) as very important ( $y=3)$ was $24 \%$ higher in Ethiopia than in Kenya. Sixteen percent more respondents in Kenya than in Ethiopia placed no importance at all on crossbreeding $(\mathrm{y}=1)$. Livestock-keepers in Ethiopia and in Kenya considered it important to keep Borana animals as a major breed (Question 6), but to slightly different degrees. 
The awareness for the threat to the survival of the Borana (Question 3) was higher in Ethiopia with 10\% more people agreeing that this is a risk $(\mathrm{y}=2)$ and $5 \%$ more people agreeing strongly $(\mathrm{y}=3)$. Eight percent more people in Kenya in fact did not see any risk $(\mathrm{y}=1)$. However, the awareness that the herd composition has changed (Question 1) was higher in Kenya than in Ethiopia (Table 3). This is a sign that in Ethiopia the Borana breed has not yet been as influenced by breeding initiatives as it has in Kenya. Awareness of the decreased availability of pure Borana cattle on local markets (Question 2) was, like the awareness for diminishing land availability (Question 5), not significantly different in both countries, but both questions were affected by the production system, as discussed in the next section.

\subsubsection{Production-specific heterogeneity}

There was a negative relationship between being a pastoralist and the extent to which people agreed that pure Borana cattle cannot be found on local markets anymore (Question 2) (see Table 3). There was a 5\% lower probability that pastoralists strongly agreed and $12 \%$ lower probability that they agreed to this statement. The share of pastoralists not agreeing $(\mathrm{y}=1)$ to this question was $16 \%$ higher for pastoralists than for agro-pastoralists. This can be explained by different markets to which pastoralists and agro-pastoralists have access to. While pastoralists were more or less constrained to local markets, agro-pastoralists seemed to cover long distances to reach more urban markets where the supply of cattle breeds is greater and more diverse (finding from in-depth interviews). This could also be because the percentage of pastoralists was higher in Kenya than in Ethiopia and the markets in Kenya might function better with a greater variety of breeds being sold.

Pastoralists were also less aware of the diminishing land (Question 5) ( $40 \%$ less for $y=3$, but $24 \%$ more for $y=1$ ). This result is not surprising because pastoralists can take their animals to distant pastures in good condition. Agro-pastoralists, on the other hand, are more constrained and in some areas their use of land for livestock competes with its use for crops.

The parameter "production system" further significantly influenced the degree to which people were aware of changes in herd composition (Question 1), with a negative relationship between the dependent variable and being a pastoralist (Table 3). Pastoralists were less likely to "strongly agree" ( $\mathrm{y}=3,37 \%$ less than agro-pastoralists) but more likely to "not agree" ( $\mathrm{y}=1,32 \%$ more) to the statement that the herd composition has changed over the last 10 years (before 2004). This result can be explained by the fact that pastoralists are not as involved in breeding with exotic and other local breeds and hence their animals might still be quite homogenous.

This consideration is corroborated by the result of question 7, the importance of crossbreeding between Borana cattle and other local breeds. Pastoralists more often (20\% more) strongly agreed ( $\mathrm{y}=3)$, while less frequently agreed ( $\mathrm{y}=2 ; 4 \%$ less) or did not agree $(\mathrm{y}=1,12 \%$ less). Pastoralists were also more likely to be unsure $(\mathrm{y}=0)$ about question 8 (importance of exotic cattle in herd), question 9 (importance of crossbreeding between exotic and Borana cattle) and question 4 (exotic breeds are inevitable for higher production). The share of pastoralists not being able to answer questions 4 and 9 was about $23 \%$ higher than that of agro-pastoralists, and $26 \%$ higher in the case of question 8. Agro-pastoralists were more likely to agree to the importance of exotic breeds (Question 8) and the importance of crossbreeding with exotic breeds (Question 9). They were also more likely to "strongly agree" to the statement imposed in question 4 (10\% more).

\subsubsection{Heterogeneity in socio-economic background}

Literate livestock-keepers were more likely to answer questions 4 and 9 positively (Table 3). This was expected because people who have attended school are also more likely to know about breeding strategies and market activities and are more exposed to the opportunity of purchasing exotic breeds in the first place. The parameter "being a village chief" was positively related to the degree of importance placed on keeping exotic breeds in the herd. This finding was also not surprising because village chiefs have high social status, special privileges and often above average wealth. They also travel frequently and visit large markets outside their regions (e.g. markets in Addis Ababa and Nairobi). They are hence often exposed to the existence of exotic breeds.

The awareness for diminishing land availability (Question 5) was affected by education and cattle herd size. The more cattle people kept, the more likely they were to be very aware of this problem. This finding was also expected because, with more cattle to feed, the greater the relevance of good pastures. People who were illiterate were less likely to have answered "strongly agree" $(\mathrm{y}=3,8 \%$ less $)$ and "agree" ( $\mathrm{y}=2,3 \%$ less) to this question

\section{Discussion}

Adjusting the breeding strategy is just one of many ways of coping with new situations but is particularly important for the Borana clan, whose cultural identity is based upon the husbandry of livestock. There are 
limited options for diversification and intensification of livelihood strategies but sources for additional income from outside the production system might be possible and necessary in the future. Some options for breeding are less favourable for the conservation of the Borana breed while some can support de-facto and on-farm conservation.

\subsection{Implications for on-farm conservation of the Borana breed}

Many studies have shown that local breeds have higher economic values than others, and that in particular adaptive traits such as disease resistance and heat tolerance are of great importance to local livestock-keepers. Zander and Drucker (2008) have shown that Ethiopian Borana people have the highest economic value from cattle breeds that are tick tolerant, have a high tolerance to water shortage and that are suitable for traction, all traits found in the Borana breed but not in exotic breeds or cross-breeds. Their findings are corroborated in this study through the analysis of livestock-keepers' perceptions towards breeding strategies. Given that the well-being of African livestock-keepers depends on keeping well-adapted local breeds, the conclusion is that breeding with exotic breeds not only threatens the survival of the Borana breed but also does not reflect most livestock-keepers' preferred breeding strategies.

Even if Borana livestock-keepers obtain better access to modern techniques in breeding and veterinary science and, have access to credit to pay for the new technologies in the future, many are more likely to maintain the Borana breed de-facto. I found country and production-specific differences of breeding preferences among respondents which could help to identify where best to establish on-farm conservation programmes for the Borana breed. In Kenya, Borana livestock-keepers were more likely to consider breeding with and keeping exotic breeds, pursuing a rise in productivity and income. Respondents in Ethiopia were found to be more likely to refrain from keeping or breeding exotic breeds, or at least they were less likely to agree that their productivity and importance was higher than that of Borana. Ethiopian livestock-keepers were also more aware of the threats to the Borana breed. This and the lack of positive views about introducing exotic breeds could be beneficial for the survival of the Borana breed. Hence, Ethiopian livestock-keepers might be more likely to keep the Borana breed de-facto. On the other hand, their lack of knowledge about exotic breeds may mean they will more readily accept them when new breeds become accessible in markets in the future, or are promoted by local NGOs or research agencies.

Based on the findings of this study, threats to the dilution of Borana genetic material seemed to be country-specific. In Kenya, the main threat was the suppression of the Borana by exotic breeds; in Ethiopia it was mainly the replacement and dilution by other local (and often inferior) breeds. In the latter case, de-facto conservation of the Borana breed might not be sufficient because livestock-keepers do not rule out crossbreeding with local breeds. Most Ethiopian livestock-keepers, and in particular pastoralists, have no breeding plans (see Tano et al. 2003) and mating is essentially random, partly because pastures are common resources and mating between herds cannot easily be controlled. On-farm conservation programmes would need to aim at better record keeping of breeding and promote breeding only with the Borana breed.

Reaping benefits from other activities related to environmental services (ES) might be an option to enhance on-farm conservation of the Borana breed. Livestock-keepers can contribute to the conservation of AnGRs and in the long run this might be a new field of income generation because this is a positive externality and can be regarded as an environmental service for which eventually the whole society will pay. The opportunity of greenhouse gas reductions to decrease the ecological footprint of the global livestock sector by controlled reduction in herd size in return for compensation payments could also be investigated as a source of additional income for Borana livestock-keepers while becoming less vulnerable to environmental hazards and becoming more sustainable (see e.g. Reid et al., 2004; Steinfeld et al., 2006).

Ensuring breed diversity can further contribute positively to risk reduction through diversification of income sources. This becomes more important with uncertainty about changes in global environments, particularly more frequent extreme weather events. Because of the long livestock production cycle, it is important to maintain a diversity of breeds as a gene pool from which one can draw when adaptation measures require it. A global gene pool of AnGRs should be secured to draw from when forced to do so after catastrophes (either natural disasters or diseases), and this can best be done using a community-based approach. Other market-based instruments besides payments for environmental services (PES), such as premium prices and niche markets could also lead to increasing de-facto conservation of livestock breeds. Further research on the value of such environmental services is needed to pay livestock-keepers appropriately for these.

\subsection{Controversies about breeding with exotic cattle in the Borana lowlands}

Nearly all respondents knew of the existence of high yielding exotic breeds in other parts of their countries. Thus, 
there could be two reasons that particular questions about breeding with exotic breeds (questions 4,8 and 9) were not answered. First, it could be that respondents lacked knowledge about how to breed with them and about the consequences, or secondly, they might be aware of the drawbacks of exotic cattle in their environments and their failure to answer was a protest against their possible introduction. As revealed in in-depth interviews, many respondents simply did not know where to obtain exotic breeds or their genetic material, or what inputs they would need (feed supplements etc.) for their maintenance. In this context, a lack of knowledge transfer (e.g. about AI) from government agencies or NGOs was also mentioned, as well as the wish for better market access which gives at least the option to purchase exotic breeding material.

However, knowledge transfer can also promote unsuitable breeding strategies, if they do not take into account livestock-keepers' perceptions and region-specific environmental constraints. Statements that pastoralists should ensure that they are breeding with high-quality males and that exotic stock will increase output have a long history in pastoral development (FAO, 2001). For Borana livestock-keepers, fast restocking of herds is often undertaken with exotic breeds with the aim of increasing productivity or with inferior local breeds with the aim of accumulating a large herd at low costs. As shown in this study, Borana livestock-keepers not only have a low positive perception for high yielding breeds, or a lack of knowledge about them, but also a lack of infrastructure. Furthermore, the difficulties of access to markets and veterinary services impede more intensive cattle production requiring a continuous service of health care and feed supplements. In the Borana lowlands inputs and services for exotic breeds are likely to be very irregular and unreliable, creating periodic shortfalls.

Crop production as fodder supply for exotic breeds is largely constrained by poor soils and low rainfall in the Borana lowlands. Further, the Borana culture, particularly in Ethiopia, is built around cattle husbandry and, in some Borana clans, crop farming is associated with poverty (because the herd is not large enough to support the family) (see Solomon et al., 2007). The knowledge of crop farming might also be lacking because it is not embedded in the Borana tradition. Unless they move to more fertile areas, crop production for Borana livestock-keepers can only be a complementary activity with marginal harvests in order to diversify the daily nutrition supply. In Kenya, leaving the lowlands and switching entirely to crop production is already on the agenda because people seem to be less bound to their cultural identity than in Ethiopia (Zander and Drucker, 2008).

\section{Conclusions}

Borana livestock-keepers' vulnerability is shaped by ecological, economic and political forces at local, national and international levels. Livestock is one of the few resources over which pastoral people have control, as compared to land, markets, and politics, which also have a large impact on their welfare. This study revealed that the awareness of changes in herd composition, of decreasing numbers of Borana cattle sold on the markets and of the need to conserve Borana genetic material is rather poor. Cross breeding between the Borana breed and other local breeds was found to be the most desired breeding strategy. It was further found that the Ethiopian livestock-keepers in particular have either no knowledge about exotic breeds for breeding or do not want them, while some of the Kenyan respondents would like to improve their productivity by interbreeding with exotic cattle. Many respondents mentioned a lack of veterinary services, inaccessibility of markets and a lack of support from extension services as the principal factors constraining the introduction of exotic breeds to their herds. Agro-pastoralists, as compared to pastoralists, were also more receptive to breeding with exotic breeds. Hence, Ethiopian pastoralists are the most likely to conserve the Borana breed de-facto, given their perceptions and preferred breeding strategies. In order to minimise the genetic dilution of the Borana breed by increasing cross-breeding with other local breeds, conservation programmes paying compensation to Ethiopian pastoralists to keep their breed "pure" could be established.

\section{Acknowledgements}

The author acknowledges the valuable comments and suggestions by Karin Holm-Mueller, Adam Drucker, John Mburu and Stephen Garnett. Funds for the field research were provided by the Robert Bosch foundation, Stuttgart, Germany.

\section{References}

Blackburn, H.D. (2007). Integrating policies for the management of animal genetic resources with demand for livestock products and environmental sustainability. Animal Genetic Resources Information, 41 (Special issue: Interlaken International Conference), FAO, Rome, Italy.

Coppock, D.L. (1994). The Borana plateau of Southern Ethiopia: Synthesis of pastoral research, development and change, 1980-1991. ILCA, Addis Ababa, Ethiopia. 
Drucker, A.G., Gomez, V., \& Anderson, S. (2001). The economic valuation of farm animal genetic resources: a survey of available methods. Ecological Economics, 36(1), 1-18.

Food and Agriculture Organisation of the United Nations (FAO). (2001). Pastoralism in the New Millenium, Animal Production and Health Paper, 150, Rome, Italy, http://www.fao.org/docrep/005/y2647e/y2647e00.htm.

FAO. (2007). The State of the World's Animal Genetic Resources for Food and Agriculture. In: B. Rischkowsky \& D. Pilling (Eds.), Rome, Italy.

Fratkin, E., \& Roth, E.A. (2005). As Pastoralists Settle. Kluwer Academic Publishers, New York and London.

Herrero, M., Thornton, P.K., Notenbaert, A.M., Wood, S., Msangi, S., Freeman, H.A., Bossio, D., Dixon, J., Peters, M., van de Steeg, J., Lynam, J., Parthasarathy Rao, P., Macmillan, S., Gerald, B., McDermott, J., Seré, C., \& Rosegrant, M. (2010). Smart investments in sustainable food production: revisiting mixed crop-livestock systems. Science, 327, 822-825.

Homann, S., Rischkowsky, B., Steinbach, J., Kirk, M., \& Mathias, E. (2008). Towards Endogenous Livestock Development: Borana Pastoralists' Responses to Environmental and Institutional Changes. Human Ecology, 36, 503-520.

International Livestock research Institute (ILRI). (2006). Drought in the Horn Begins to Break - but the Crisis will Get Worse before it Gets Better. Livestock in the News: Horn of Africa Crises, http://www.ilri.org.

IPCC. (2007). Climate Change 2007: Impacts, Adaptation and Vulnerability. Contribution of Working Group II to the Fourth Assessment Report of the Intergovernmental Panel on Climate Change. Cambridge University Press, Cambridge, UK, 976pp.

Kamara, A.B. (2000). Ethiopian case study. In: N. Mc Carthy, B. Swallow, M. Kirk \& P. Hazell (Eds.), Property rights, risk, and livestock development in Africa. Washington and Nairobi, IFPRI, 396-426.

Omondi, I., Baltenweck, I., Drucker, A.G., Obare, G., \& Zander, K.K. (2008). Economic Valuation of Sheep Genetic Resources: Implications for Sustainable Utilization in the Kenyan Semi-arid Tropics. Tropical Animal Health and Production, 40(8), 615-626.

Ouma, E., Abdulai, A., \& Drucker, A. (2007). Measuring Heterogeneous Preferences for Cattle Traits among Cattle-Keeping Households in East Africa. American Journal of Agricultural Economics, 89(4), 1005-1019.

Reid, R.S., Thornton, P.K., Mc Crabb, G.L., Kruska, R.L., Atieno, F., \& Jones, P.G. (2004). Is it possible to mitigate greenhouse gas emissions in pastoral ecosystems of the tropics? Environment, Development and Sustainability, 6, 91-109.

Ruto, E., Garrod, G., \& Scarpa, R. (2008). Valuing animal genetic resources: a choice modeling application to indigenous cattle in Kenya. Agricultural Economics, 38(1), 89-98.

Schlee, G., 1989. Identities on the Move: Clanship and Pastoralism in Northern Kenya. Manchester University Press, Manchester, UK.

Solomon, T.B., Snyman, H.A., \& Smit, G.N. (2007). Cattle-rangeland management practices and perceptions of pastoralists towards rangeland degradation in the Borana zone of southern Ethiopia. Journal of Environmental Management, 82, 481-494.

Steinfeld, H., Gerber, P., Wassenaar, P., Castel, V., Rosales, M., \& de Haan, C. (2006). Livestock's long shadow: environmental issues and options. FAO, Rome, Italy.

Tano, K., Kamuanga, M., Faminow, M.D., \& Swallow, B. (2003). Using conjoint analysis to estimate farmer's preferences for cattle traits in West Africa. Ecological Economics, 45, 393-407.

Verbeek, M. (2000). A Guide to modern econometrics. Wiley, Chichester, UK.

Vidogbèna, F., Adégbidi, A.A., Garnett, S.T., Koudandé, D.O., Agbo, V., \& Zander, K.K. (2010). Peace, health or fortune?: Preferences for chicken traits in rural Benin. Ecological Economics, 69(9), 1849-1858

Zander, K.K., \& Drucker, A.G. (2008). Conserving what's important: using choice model scenarios to value local cattle breeds in East Africa. Ecological Economics, 68(1-2), 34-45.

Table 1. Household characteristics in research area

\begin{tabular}{|l|c|c|c|}
\hline & Ethiopia & Kenya & All \\
\hline
\end{tabular}




\begin{tabular}{|l|c|c|c|}
\hline & $(\mathrm{N}=244)$ & $(\mathrm{N}=120)$ & $(\mathrm{N}=364)$ \\
\hline Pastoralists & $\begin{array}{c}45 \text { households } \\
(16 \%)\end{array}$ & $\begin{array}{c}71 \text { households } \\
(59 \%)\end{array}$ & $\begin{array}{c}116 \text { households } \\
(32 \%)\end{array}$ \\
\hline Rate of literacy & $\begin{array}{c}132 \text { households } \\
(54 \%)\end{array}$ & $\begin{array}{c}98 \text { households } \\
(82 \%)\end{array}$ & $\begin{array}{c}230 \text { households } \\
(63 \%)\end{array}$ \\
\hline Village chief & $\begin{array}{c}26 \text { households } \\
(11 \%)\end{array}$ & $\begin{array}{c}9 \text { households } \\
(8 \%)\end{array}$ & $\begin{array}{c}35 \text { households } \\
(10 \%)\end{array}$ \\
\hline Annual income from cattle production & $\begin{array}{c}€ 77 \\
(\text { Std. Dev.: } 191)\end{array}$ & $\begin{array}{c}€ 84 \\
(\text { Std. Dev.: } 403)\end{array}$ & $\begin{array}{c}€ 79 \\
(\text { Std. Dev.: 278) }\end{array}$ \\
\hline Female headed household & $\begin{array}{c}16 \text { households } \\
(7 \%)\end{array}$ & $\begin{array}{c}2 \text { households } \\
(2 \%)\end{array}$ & $\begin{array}{c}18 \text { households } \\
(5 \%)\end{array}$ \\
\hline Hers size (adult animals) & $\begin{array}{c}18 \\
(\text { Std. Dev.: } 16)\end{array}$ & $\begin{array}{c}20 \\
\text { (Std. Dev.: 20) }\end{array}$ & $\begin{array}{c}19 \\
\text { (Std. Dev.: } 18)\end{array}$ \\
\hline
\end{tabular}

Table 2. Proportion of selected rates on Likert scale

\begin{tabular}{|c|l|r|r|r|r|}
\hline Question & Response* & $\mathrm{y}=1$ & $\mathrm{y}=2$ & $\mathrm{y}=3$ & $\mathrm{y}=0$ \\
\hline 1 & Awareness of change of herds & $32 \%$ & $25 \%$ & $40 \%$ & $3 \%$ \\
\hline 2 & Hard to find Borana cattle on markets & $65 \%$ & $27 \%$ & $6 \%$ & $1 \%$ \\
\hline 3 & Awareness of risk of Borana cattle extinction & $64 \%$ & $23 \%$ & $6 \%$ & $7 \%$ \\
\hline 4 & Exotic cattle inevitable for higher production & $30 \%$ & $13 \%$ & $17 \%$ & $41 \%$ \\
\hline 5 & Awareness of decreasing pasture & $11 \%$ & $7 \%$ & $79 \%$ & $2 \%$ \\
\hline 6 & Importance of Borana cattle in herd & $4 \%$ & $27 \%$ & $69 \%$ & $1 \%$ \\
\hline 7 & Importance of crossing Borana with local breeds & $23 \%$ & $34 \%$ & $38 \%$ & $4 \%$ \\
\hline 8 & Importance of rearing exotic breeds & $29 \%$ & $17 \%$ & $16 \%$ & $38 \%$ \\
\hline 9 & Importance of crossing Borana with exotic breeds & $19 \%$ & $20 \%$ & $15 \%$ & $46 \%$ \\
\hline
\end{tabular}

* $\mathrm{y}=1$ is either "do not agree" or "not important"; $\mathrm{y}=2$ is either "partly agree" or "important"; $y=3$ is either "very important" or "fully agree"; $y=0$ is "do not know" 
Table 3. Results of ordered probit models

\begin{tabular}{|c|c|c|c|c|c|c|c|c|c|}
\hline & 1 & 2 & 3 & 4 & 5 & 6 & 7 & 8 & 9 \\
\hline & $\begin{array}{l}\text { Awareness } \\
\text { of change } \\
\text { of herds }\end{array}$ & $\begin{array}{l}\text { Hard to } \\
\text { find } \\
\text { Borana } \\
\text { cattle on } \\
\text { markets }\end{array}$ & $\begin{array}{l}\text { Awareness } \\
\text { of risk of } \\
\text { Borana } \\
\text { cattle } \\
\text { extinction }\end{array}$ & $\begin{array}{l}\text { Exotic } \\
\text { cattle } \\
\text { inevitable } \\
\text { for higher } \\
\text { production }\end{array}$ & $\begin{array}{l}\text { Awareness } \\
\text { of } \\
\text { decreasing } \\
\text { pasture }\end{array}$ & $\begin{array}{l}\text { Importance } \\
\text { of Borana } \\
\text { cattle in } \\
\text { herd }\end{array}$ & $\begin{array}{l}\text { Importance } \\
\text { of crossing } \\
\text { Borana } \\
\text { with local } \\
\text { breeds }\end{array}$ & $\begin{array}{l}\text { Importance } \\
\text { of rearing } \\
\text { exotic } \\
\text { breeds }\end{array}$ & $\begin{array}{l}\text { Importance } \\
\text { of crossing } \\
\text { Borana } \\
\text { with exotic } \\
\text { breeds }\end{array}$ \\
\hline Constant & $2.126^{* * *}$ & $2.491 * * *$ & $1.658 * * *$ & $-0.252 * *$ & $2.748 * * *$ & $2.777 * * *$ & $2.229 * * *$ & $-0.523 * * *$ & $-0.483 * * *$ \\
\hline Kenya & $0.889 * * *$ & & $-0.450 * * *$ & $1.637 * * *$ & & $-0.541 * * *$ & $-0.658 * * *$ & $1.913 * * *$ & $1.685^{* * *}$ \\
\hline Literate & & & & $0.411 * * *$ & $-0.325^{* *}$ & & & & $0.526 * * *$ \\
\hline Pastoralism & $-1.087 * * *$ & $-0.509 * * *$ & & $-0.597 * * *$ & $-1.351 * * *$ & & $0.510 * * *$ & $-0.706^{* * *}$ & $-0.603 * * *$ \\
\hline N_cattle & & & & & $0.019 * * *$ & & & & \\
\hline Age & & & & & & & $-0.008^{* *}$ & $0.010 * *$ & \\
\hline Female & & & & & & & & $0.548^{* *}$ & \\
\hline Chief & & & & & & & & $0.471 * *$ & \\
\hline$\mu_{1}$ & $1.62 * * *$ & $2.76^{* * *}$ & $2.07 * * *$ & $1 * * *$ & $1.12 * * *$ & $0.87 * * *$ & $1.17 * * *$ & $1.01 * * *$ & $0.65 * * *$ \\
\hline$\mu_{2}$ & $2.34^{* * *}$ & $3.9 * * *$ & $3.08^{* * *}$ & $1.62 * * *$ & $1.49 * * *$ & $2.09 * * *$ & $2.13 * * *$ & $1.82 * * *$ & $1.64 * * *$ \\
\hline Log-likelihood & -398.54 & -305.83 & -351.14 & -394.42 & -216.03 & -272.60 & -423.75 & -391.55 & -384.27 \\
\hline Chi squared & $64.75^{* * *}$ & $13.26^{* * *}$ & $11.96 * * *$ & $148.01 * * *$ & $81.80 * * *$ & $15.69 * * *$ & $32.64 * * *$ & $175.29 * * *$ & $161.27^{* * *}$ \\
\hline D.o.f & 2 & 1 & 1 & 3 & 3 & 1 & 3 & 5 & 3 \\
\hline
\end{tabular}

$* * * 1 \%$ significance level; $* *=5 \%$ significance level

Table 4. Marginal effects

\begin{tabular}{|c|c|c|c|c|c|c|c|c|c|c|}
\hline & & 1 & 2 & 3 & 4 & 5 & 6 & 7 & 8 & 9 \\
\hline & & $\begin{array}{l}\text { Awareness } \\
\text { of change } \\
\text { of herds }\end{array}$ & $\begin{array}{l}\text { Hard to } \\
\text { find } \\
\text { Borana } \\
\text { cattle on } \\
\text { markets }\end{array}$ & $\begin{array}{l}\text { Awareness } \\
\text { of risk of } \\
\text { Borana } \\
\text { cattle } \\
\text { extinction }\end{array}$ & $\begin{array}{l}\text { Exotic } \\
\text { cattle } \\
\text { inevitable } \\
\text { for } \\
\text { production }\end{array}$ & $\begin{array}{l}\text { Awareness } \\
\text { of } \\
\text { decreasing } \\
\text { pasture }\end{array}$ & $\begin{array}{l}\text { Importance } \\
\text { of Borana } \\
\text { cattle in } \\
\text { herd }\end{array}$ & $\begin{array}{l}\text { Importance } \\
\text { of crossing } \\
\text { Borana } \\
\text { with local } \\
\text { breeds }\end{array}$ & $\begin{array}{l}\text { Importance } \\
\text { of rearing } \\
\text { exotic } \\
\text { breeds }\end{array}$ & $\begin{array}{l}\text { Importance } \\
\text { of crossing } \\
\text { Borana } \\
\text { with exotic } \\
\text { breeds }\end{array}$ \\
\hline \multirow{7}{*}{$\prod_{\nu}$} & Kenya & $-0.034 * * *$ & & $0.065 * * *$ & $-0.499 * * *$ & & $0.010 * * *$ & $0.064 * * *$ & $-0.531 * * *$ & $-0.545 * * *$ \\
\hline & Literate & & & & $-0.156^{* * *}$ & $0.006^{* * *}$ & & & & $-0.206^{* * *}$ \\
\hline & Pastoralism & $0.084^{* * *}$ & $0.017^{* * *}$ & & $0.228^{* *}$ & $0.060^{* * *}$ & & $-0.034^{* * *}$ & $0.263^{* * *}$ & $0.236^{* * *}$ \\
\hline & N_cattle & & & & & $-0.0004^{* * *}$ & & & & \\
\hline & Age & & & & & & & 0.001 & -0.004 & \\
\hline & Female & & & & & & & & $-0.171^{* * *}$ & \\
\hline & Chief & & & & & & & & $-0.152^{* * *}$ & \\
\hline \multirow{7}{*}{$\stackrel{\pi}{\nu}$} & Kenya & $-0.255^{* * *}$ & & $0.081 * * *$ & -0.058 & & $0.048 * * *$ & $0.161 * * *$ & $-0.117 * * *$ & $-0.051 * * *$ \\
\hline & Literate & & & & 0.027 & $0.044^{* * *}$ & & & & 0.022 \\
\hline & Pastoralism & $0.317^{* * *}$ & $0.158^{* * *}$ & & $-0.049^{* * *}$ & $0.239^{* * *}$ & & $-0.120^{* * *}$ & $-0.044^{* * *}$ & $-0.031^{* * *}$ \\
\hline & N_cattle & & & & & $-0.003^{* * *}$ & & & & \\
\hline & Age & & & & & & & $0.002^{* * *}$ & 0.0002 & \\
\hline & Female & & & & & & & & $-0.035^{* * *}$ & \\
\hline & Chief & & & & & & & & $-0.021^{* * *}$ & \\
\hline \multirow{7}{*}{$\underset{\nu}{\pi}$} & Kenya & $-0.052 * * *$ & & $-0.099 * * *$ & 0.159 & & $0.139 * * *$ & 0.011 & 0.205 & $0.236 * * *$ \\
\hline & Literate & & & & 0.059 & 0.027 & & & & $0.114 * * *$ \\
\hline & Pastoralism & -0.027 & $-0.124^{* * *}$ & & $-0.085^{* * *}$ & 0.100 & & $-0.042^{* * *}$ & $-0.125^{* * *}$ & $-0.130^{* * *}$ \\
\hline & N_cattle & & & & & -0.002 & & & & \\
\hline & Age & & & & & & & 0.0004 & $0.002^{* * *}$ & \\
\hline & Female & & & & & & & & 0.089 & \\
\hline & Chief & & & & & & & & 0.080 & \\
\hline \multirow{7}{*}{$\stackrel{\pi}{\|}$} & Kenya & $0.341 * * *$ & & $-0.047 * * *$ & $0.399 * * *$ & & $-0.196 * * *$ & $-0.236 * * *$ & $0.442 * * *$ & $0.360 * * *$ \\
\hline & Literate & & & & $0.069^{* * *}$ & $-0.077^{* * * *}$ & & & & $0.070^{* * *}$ \\
\hline & Pastoralism & $-0.374^{* * *}$ & $-0.052^{* * *}$ & & $-0.094^{* * *}$ & $-0.399^{* * *}$ & & $0.196^{* * *}$ & -0.094 & -0.076 \\
\hline & $\mathrm{N}$ cattle & & & & & $0.005^{* * *}$ & & & & \\
\hline & Age & & & & & & & $-0.003^{* * *}$ & 0.002 & \\
\hline & Female & & & & & & & & $0.117^{* * *}$ & \\
\hline & Chief & & & & & & & & $0.094^{* * *}$ & \\
\hline
\end{tabular}

$* * * 1 \%$ significance level; $* *=5 \%$ significance level 